\title{
Distribution and Revenue Sharing of Natural Resources in Indonesia: Autonomous Region and Legal Pluralism Perspective
}

\author{
Putu Gede Arya Sumerta Yasa*
}

Faculty of Law, Universitas Udayana, Bali, Indonesia

\begin{abstract}
The distribution and revenue sharing of natural resources in Indonesia is considered a very important issue. The exploitation of natural resources of a particular region can be implemented by referring to the concept of regional autonomy. In practice, not all regional governments can take advantage of the natural resources situated in the region. The research aims to review and analyze the arrangement of revenue sharing and natural resources based on the principle of decentralization in the balance of national and regional finances in Indonesia and analyze the autonomous region in Indonesia from a legal pluralism perspective. This study is normative legal research using statutory, conceptual, and analytical approaches. The results suggested that the arrangement of the division of funds for revenue based on decentralization in Indonesia has not fully reflected the principle of proportionality, as it is perceived not providing just and proper share for some regions. In achieving public welfare and social justice at the lowest level of governance, the existence of customary villages in Bali may serve as a solution in addressing the issue of regional management on natural resources along with its potential benefits. Parallel to this concern, the customary village can also play an indirect role in achieving justice, equity, and harmony in the regions. Therefore, the synergy between the national and regional governments, induding customary villages undoubtedly reflects legal pluralism.
\end{abstract}

Keywords: Local government; Natural resources; Autonomous region; Revenue sharing; Customary village.

\section{INTRODUCTION}

The dynamics of fiscal decentralization in the last three decades put the distribution and revenue sharing of natural resources in Indonesia becoming a very important issue. ${ }^{1}$ It is one of the financial problems in the administration of government, both at the national government and local government, due to their interests to raise sources of funds through the authority given by the legislation.

Natural resources can be conceived as everything that comes from nature and is utilized to meet the needs of people's lives, which includes fisheries, forestry, water, and non-renewable sources. ${ }^{2}$ The components of

\footnotetext{
** Email/Corresponding Author: arva sumerthavasa@unud.ac.id

1 Rov Rah1 and Ravar Tiımennasan. "How should revenues from natiural resniurces be shared in Indonesia?." In Reformina Interaovernmental Fiscal Relations and the Rebuildina of Indonesia: The'Bia Bana'Proaram and its Economic Conseauences. ed. James Alm. Jorge Martinez-Vazquez, Sri Mulyani Indrawati, (United Kingdom: Edward Elgar, 2004), 222.

2 Ouentin Grafton. et.al. The economics of the environment and natural resources. (New York: John Wiley \& Sons, 2008), 125.
} 
natural resources are not only in the form of animals, plants, or other biotic components. In practice, abiotic components may also be classified as natural resources such as natural gas, petroleum, water, soil, and various metals that are used to meet the needs of the life of human beings.

Exploitation shall be done appropriately and wisely by paying attention to natural conditions and carried out for the benefit of the community. Ideally, the exploitation of natural resources in an area shall be aimed at meeting the needs as well as increasing the prosperity of the people around the area. ${ }^{3}$ From a sharing of authority perspective, natural resource exploitation may be exercised by a region under a regional autonomy framework that allows the region to regulate its households, managing natural resources in the area, and allocating funds as a result of its utilization. ${ }^{4}$

In practice, facts showed that not all regions can take advantage of the natural resources in their area. As an example, there is a case where areas with plentiful resources in a region are not classified as natural resources, entailing that local government has no authority to exploit them. There are also areas known for abundant natural resources but its people still live in poor and alarming conditions. In addition, some regions in the same province fight for a just and equal share of funds resulted from natural resources utilization. The demands for improvement in financial management in the regions are then motivated by the spirit of regional autonomy as stipulated in Law No. 32 of 2004 concerning Regional Government and Law No. 33 of 2004 concerning National and Regional Financial Balance.

This research aims to analyze, observe, and elaborate the arrangement of revenue-sharing for natural resources based on the principle of decentralization under the framework of the financial balance of national and regional governments in Indonesia. ${ }^{5}$ This study also examines the application of regional autonomy in accordance with the concept of legal pluralism. First, it examines the division of regional autonomous-based natural resources in Indonesia. Second, it analyzes the regional autonomy in Indonesia from the perspective of legal pluralism, by using Bali as an example.

Previous research, for example, conducted by Ledyawati in $2017^{6}$ and Johan Erwin Isharyanto in $2018^{7}$ studied the authority of local governments

${ }^{3}$ Cheikh Mbow, et. al, "Land resources opportunities for a growing prosperity in the Sahel." Current Opinion in Environmental Sustainability 48 (2021): 88.

4 Jesse C. Ribot, et. al, "Recentralizing While Decentralizing: How National Governments Reappropriate Forest Resources.” World Development 34, no.11 (2006): 1865.

5 Some basic ideas were presented in a paper written bv the Author in a Discussion organized by Lembaga Administrasi Negara (Institute of Public Administration), at Faculty of Law Udayana University, Denpasar, 12-13 June 2013.

${ }^{6}$ Ledyawati, "Kewenangan Pemerintah Daerah Dalam Pengelolaan Sumber Daya Alam Pertambangan Minerba di Era Otonomi Daerah," Jumal Agregasi: Aksi Reformasi Government dalam Demokrasi 5, no. 1 (2017): 39. 
within the framework of regional autonomy. Even the present article reflects the same topic, it has a different focus, that is to examine the regulation or arrangement of revenue-sharing funds and natural resources based on the principle of decentralization in the balance of National and regional finance in Indonesia and regional autonomy in accordance with the concept of legal pluralism.

This article is normative legal research that uses statutory, conceptual, and analytical approaches. The statutory approach is used to describe laws and regulations at both national and regional levels that have relevance to the topic discussed. The conceptual and analytical approaches are applied to explain as well as provide an advanced understanding of the legal concept of regional autonomy, source of revenue, and authority of local government.

\section{RESULT AND ANALYSIS}

\subsection{Division of Natural Resources Based on Autonomous Regions in Indonesia}

The 1945 Constitution of the Republic of Indonesia (hereinafter, Indonesian Constitution, is the fundamental rule that regulates the relationship between the national government and the regions. In the context of territorial division, Indonesia is divided into provinces, and the provinces are further divided into regencies and cities. 8 The authority relations between those levels of governments are regulated by having regard to the particularities and diversity of each region. ${ }^{9}$ In addition, the relations between the national government and the regions concerning finances, public services, and the use of natural and other resources are regulated and implemented with justice and equity. ${ }^{10}$

In implementing decentralization to those divided areas, the national governments and the regions should manage a harmonious relationship. ${ }^{11}$ Cheema and Rondinelli conceive three forms of decentralization, namely "The Act as a way for transferring authority, responsibility, and resources; through deconcentration, delegation or devolution; from the center to lower levels of administration". ${ }^{12}$ This concept is in line with the basic principle of

7 Johan Erwin Isharyanto, "Pengelolaan Sumberdaya Perikanan Dalam Kerangka Undang-Undang Otonomi Daerah." Jurnal Imiah Hukum Dan Dinamika Masyarakat 15, no. 1 (2018): 34.

8 The 1945 Constitution of the Republic of Indonesia, Art. 18 (1).

9 Ibid., Art. 18A (1).

10 Ibid., Art 18A (2).

11 Abdul Rauf Alauddin Said, "Pembagian Kewenangan Pemerintah PusatPemerintah Daerah Dalam Otonomi Seluas-Luasnya Menurut UUD 1945." Fiat Justisia: Jurnal Ilmu Hukum 9, no. 4 (2015): 593.

12 Rachmat Hidayat, "Political Devolution: Lessons From A Decentralized Mode of Government in Indonesia." SAGE open 7, no. 1 (2017): 1. 
decentralization in Indonesia that allows regional governments to manage their own budget. ${ }^{13}$

The improvement of local government laws and regulations and the balance of national and regional finances are expected to enable the flexibility of the regions to fulfill the needs of the people in the regions. It reflects the State's purpose to foster public welfare and social justice as stipulated in the Indonesian Constitution.

Law No. 17 of 2003 on State Finances stipulates that the financial administration of the state have principles related to the rules of good state administration:

1. Result-oriented accountability (money follows function);

2. Profe ssionalism;

3. Proportionality;

4. Openness in management; and

5. Financial audit by an independent audit body.

These principles are related to the rules of good state administration, especially with regards to the relationship between the national and regional governments that refers to the granting of authority to the regions as stipulated in Law No. 23 of 2014 concerning Regional Government (hereinafter Regional Government Law). ${ }^{14}$

Improvements in the financial sector in the relationship between the national and local governments include the legal framework for the distribution of national resources. ${ }^{15}$ It gives great hope for changes towards a more democratic, transparent, and accountable state administration as well as the realization of good governance. As regional governance is carried out with the principle of autonomy, ${ }^{16}$ regions are allowed to take initiative in formulating regional policies, adopt implementation tools, regulate and explore sources of finance in the form of regional taxes and retributions. Therefore, regions are entitled for managing regional assets, collecting regional taxes and levies, and obtaining other legitimate sources of income. Law No. 28 of 2009 concerning Regional Taxes and Levies. Under this law, the distribution of revenue-sharing funds, the land, and building taxes, as

13 Ehtisham Ahmad and Ali Mansoor. "Indonesia: Managing Decentralization." in Manaaina Fiscal Decentralisation ed. Ethisham Ahmad and Vito Tanzi (London and New York: Routledge, 2002): 2.

14 See Fatkhul Muin, "Otonomi Daerah Dalam Perspektif Pembagian Urusan Pemerintah-Pemerintah Daerah dan Keuangan Daerah." Fiat Justisia 8, no. 1 (2014): 75.

15 See: the Decree of the People's Consultative Assembly No: I/MPR/2003 concerning the Review of the Material and Legal Status of the Decree of the People's Consultative Assembly of the Republic of Indonesia 1960 to 2002 in Article 4 point 3 of the Decree of the People's Consultative Assembly of the Republic of Indonesia No. XV/MPR /1998 on the implementation of regional autonomy; Settings; division; and equitable utilization of national resources; and Central and regional financial balance in the framework of the Unitary State of the Republic of Indonesia

16 Listijowati. "Tinjauan Yuridis Kedudukan dan Hubungan antara DPRD Dan Pemerintah Daerah Menurut UU. 32 Tahun 2004 Tentang Pemerintah Daerah." Justice Pro: Jurnal Ilmu Hukum 2, no. 1 (2018): 54. 
well as land and building rights acquisition fees, have been handed over to regencies or municipalities, except for land or areas used for plantation, forestry, and mining activities. This type of tax is not entirely profitable for the regions because there are areas where land/buildings do not have a high value, especially in dry or poor areas. Thus, the type of tax that produces the most income in the region that is submitted or made the object of profit-sharing tax is related to the geographical conditions of the region.

Article 285 Regional Government Law determines that sources of regional income consist of:

1. Local revenue,

2. Levies and;

3. The results of the management of regional assets set aside; and

4. Other areas of legitimate revenue (Income transfer and Other regions legitimate income)

The balancing fund as a source of regional financial revenue consists of revenue-sharing funds, general allocation funds, and special allocation funds". ${ }^{17}$ The arrangement of financial distribution between the national government and the regions is regulated in Law No. 33 of 2004 concerning the Financial Balance between the National Government and Regional Governments. The arrangement of revenue-sharing funds between the National and local governments consists of the tax and natural resources sectors. Thus, the legislation in natural resources should be treated better than other fields, given the urgency for the public interest, which involves revenue sharing. ${ }^{18}$

The natural resource sector that is used as the object of profit-sharing funds are:
a. Forestry;
b. General mining;
c. Fishery;
d. Petroleum mining;
e. Natural gas mining; and
f. Geothermal mining.

The concept of financial balance between the government and local governments is a fair, proportional, democratic, transparent, and efficient distribution system in the framework of funding the implementation of decentralization. This takes into consideration the potential, conditions, and needs of the region as well as the amount of funding for the implementation of deconcentration and co-administration tasks. ${ }^{19}$ It is a general practice

17 Irfan Ferdiansyah, et. al. "Pengaruh Pendapatan Asli Daerah, Dana Alokasi Umum, Dana Alokasi Khusus, dan Dana Perimbangan Terhadap Belanja Daerah." Inovasi 14 , no. 1 (2018): 45 .

18 Herdiansyah Hamzah, "Legal Policy of Legislation in the Field of Natural Resources in Indonesia." Hasanuddin Law Review 1, no. 1 (2016): 110.

19 Anggit Sulistiawan, et. al., "Bentuk Dan Mekanisme Perencanaan Keuangan Daerah Yang Partisipatif Guna Mewujudkan Akuntabilitas Publik." Jurnal Pembangunan Hukum Indonesia 1, no. 2 (2019): 147. 
that both national and regional governments conducted revenue sharing in distributing natural resource revenues. ${ }^{20}$

Table 1.

Percentage of Revenue Sharing Fund on Natural Sources ${ }^{21}$

\begin{tabular}{lrr}
\hline Natural Sources & National & Regional \\
\hline Forestry & $20 \%$ & $80 \%$ \\
\hline General mining & $20 \%$ & $80 \%$ \\
\hline Fishery & $20 \%$ & $80 \%$ \\
\hline Petroleum (Oil) mining & $84,5 \%$ & $15 \%$ \\
\hline Natural gas mining & $69,5 \%$ & $30 \%$ \\
\hline Geothermal mining & $20 \%$ & $80 \%$ \\
\hline
\end{tabular}

According to Table 1, the revenue sharing fund is from forestry, general mining, fishery, petroleum mining, natural gas mining, and geothermal mining. ${ }^{22}$ However, there are differences in revenue-sharing funds on natural sources. Table 1 shows that the regional government received more revenue sharing than the National Government for the same category of natural resources. For instance, the regional government shall receive $80 \%$ of the revenue sharing in the general mining sector, while the national government only received $20 \%$. This percentage of revenue sharing also applies in the fishery sector, forestry sector, and geothermal mining sector. However, in petroleum mining and natural gas mining, the national government shall receive more revenue sharing than the regional government. It indicates a form of state control and that the state should, if able, directly manage natural resources. ${ }^{23}$ Hence, the concept of decentralization seemed to change the fiscal relationship between the national and the regional government, a relationship in which natural resource revenue-sharing plays a significant role. ${ }^{24}$

In 2011, there was a judicial review before the Constitutional Court of the Republic of Indonesia (the Indonesian Constitutional Court) to Law No. 33 of 2004 about the percentage of revenue sharing on oil and gas mining that is increasingly demanded by the regions. In Decision No.71/PUU-

20 See Anna Louise Strachan. "Oil and Gas Revenıe Sharing." Vol. 112.3. GSDRC Helpdesk Research Report, 201. 1. http: / / www.gsdrc.org/docs/open/hdq1123.pdf

21 David Manley, Rani Febrianti and Hari Subhash, "Tangled Web: The Role of Oil, Gas and Mining in Funding Regional Government in Indonesia," Natural Resource Governance Institute, January 2020, 37. Each oil and natural gas remain 0,5\% is allocated for educational expenditures.

22 Yohanes Maria Vianey Mudayen and Herry Maridjo. "The Impacts of Fiscal Decentralization, Institutional Transformation, and Regional Revenue on Income Disparities Between Provinces in Indonesia." Journal of Economics, Business, \& Accountancy Ventura 20, no. 3 (2018): 250.

23 Simon Butt and Fritz Edward Siregar. "State Control over Natural Resources in Indonesia: Implications of the Oil and Natural Gas Law Case of 2012." Journal of Energy \& Natural Resources Law 31, no. 2 (2013): 116.

${ }^{24}$ Armida S. Alisjahbana, "7. Does Indonesia have the Balance Right in Natural Resource Revenue Sharing?." In The politics and economics of Indonesia's natural resources, ed. Budy P. Resosudarmo (Singapore: ISEAS Publishing, 2005), 109. 
IX/2011, the Indonesian Constitutional Court decided that the regulation provided in that Law is not incompatible with the Indonesian Constitution, and therefore did not grant the claim. ${ }^{25}$

Bali, a province that consists of 8 regencies and 1 city, is an example of a peculiar case regarding the sharing revenue. For decades, Bali relies on tourism as a source of finance. One of the most potential incomes is visa on Arrival (VoA) along with levies in airport and ports are not part of regional revenue for Bali, but lies to the national government. Case on oil and gas as well as tourism sector represents that the balance of national and regional finance cannot fulfill the sense of justice, especially for regions that rely upon their income from those sectors.

\subsection{Autonomous Regions in Indonesia in the Perspective of Legal Pluralism}

Article 18B paragraph (2) of the Indonesian Constitution recognized the existence of customary law and customary community along with their traditional rights as long as it still exists and in accordance with the development of society and the prevailing law and principles in Indonesia. ${ }^{26}$ An example of customary practices in Indonesia can refer to Bali Province. Masyarakat adat (customary community) in Bali, as well as in other areas in Indonesia, has the authority to manage natural resources based on genealogical rights, inherited from their ancestors even before the existence of the Republic of Indonesia. Therefore the natural resources cannot be separated from their existence. Desa Adat (customary village) is a customary-based institution in Bali that organizes the life of its community members in a specific territory in Bali based on customary law. The customary village has autonomy in 3 (three) aspects, namely: 1) to establish its own customary law (e.g awig-awig, pararem, and other customary village decisions); 2) to implement the governance based on customary law; and 3) to apply customary law in resolving customary problems and cases that occur in customary village s. ${ }^{27}$

Referring to Article 18B paragraph (2) of the Indonesia Constitution, the Government of Bali issued several regulations to maintain the harmony of Bali. As an example, the Bali Governor Regulation No. 26 of 2020 concerning Integrated Environmental Security System Based on Customary Village (hereinafter Governor Regulation No. 26/2020) aims to embody the integrated environmental security system through the customary village in

25 Justices of the Consitutional Court in the conlusion of the Decision No.71/PUUIX/2011 found that the provisions of Article 14 letter e and letter $f$ of the Financial Balance Between the National Government and Local Government does not contradict with the Indonesian Constitution, 209.

${ }^{26}$ Putri Triari Dwijayanthi, et. al., "Indigenous people, economic development and sustainable tourism: A comparative analysis between Bali, Indonesia and Australia." Udayana Journal of law and Culture 1, no. 1 (2017): 20.

27 Anak Agung Istri Ari Atu Dewi, "Eksistensi Otonomi Desa Pakraman dalam Perspektif Pluralisme Hukum." Jurnal Magister Hukum Udayana 3, no. 3 (2014). 522. 
order to purify and maintain the sustainability of natural resources in Bali, which is known as wana kerthi (forestry) and segara kerthi (fisheries). ${ }^{28}$

The existence of customary villages is regulated through the Bali Provincial Regulation No. 4 of 2019 concerning Customary Villages (hereinafter the Customary Village Regulation). ${ }^{29}$ This regulation recognizes that natural resources are a part of padruwen desa adat, which means that it is considered to be material assets of the customary village for the sake of community prosperity. ${ }^{30}$ As an instance, the local government works jointly with the Selat customary village in Buleleng regency, called Village-Owned Enterprises (BUM Des) to protect the forest and its surrounding as a part of natural resources. ${ }^{31}$ A similar concept is also implemented in Pemuteran village, Buleleng Regency by establishing Pecalang Segara (seashore security) to maintain their fisheries ecosystem that is part of essential natural resources for the livelihood of the community. ${ }^{32}$

The synergy between the government and customary villages can be seen from the perspective of legal pluralism. Legal pluralism is understood as a condition in which the validity of the law is more than one legal system. An understanding of the applicability of legal pluralism in Indonesia is visible because of the recognition of the applicability of people's law and state law that is harmonized with state law. ${ }^{33}$

Legal pluralism provides an overview of synergy between one legal system and another legal system together in a certain activity and relationship. ${ }^{34}$ Synergy in legal pluralism is reflected in Indonesia through the recognition of the existence of various types of laws, including customary law. This is also well reflected in Bali due to the application of customary law in the daily life of the people.

28 Dinas Pemajuan Masyarakat Adat Pemerintah Bali, "Visi dan Misi," https:/ / dpma.bali prov.go.id/visi-dan-misi/

29 See: Bali Provincial Regulation No. 4 of 2019 concerning Customary Villages, Art. 1 point (8) which stipulates that: Customary Villages are understood as a unit of customary law community in Bali which has territory, position, original structure, traditional rights, own assets, traditions, manners of community life from generation to generation in the bonds of sacred places (Kahyangan Tiga or kahyangan desa), duties and authorities as well as the right to regulate and manage their own household."

30 Bali Provincial Regulation No. 4 of 2019 concerning Customarv Villa ges

31 I Wavan Rideng. et. al. "Model pengelolaan hutan desa berbasis de sa adat di de sa Selat, kabupaten Buleleng." Communitu Service Joumal (CSJ 1. no. 1 (2018): 13.

32 Anantatiwikrama Tungoa Atmadia. Nengah Bawa Atmadia. and Tuti Marvati. "Pecalang Segara: Satuan Tugas Keamanan Tradisional Peniaga Kelestarian Lingkungan Pantai dan Laut: Studi Kasus di Desa Pakraman Pemuteran, Grokgak, Buleleng, Bali." Jumal Bumi Lestari 13, no. 1 (2013): 178.

33 See I Nyoman Nurjaya, "Perkembangan Pemikiran Konsep Pluralisme Hukum." Paper presented in Konferensi Internasional tentang Penguasaan Tanah dan Kekayaan Alam di Indonesia yang Sedang Berubah: "Mempertanyakan Kembali Berbagai , Jakarta.(2004): 117.

34 Baktu Bakti. "Pluralisme Hukum dalam Mekanisme Penyelesaian Sengketa Sumber Daya Alam di Aceh.” Kanun Jumal Ilmu Hukum 17, no. 1 (2015): 135. 
John Griffiths distinguished two kinds of legal pluralism, namely weak legal pluralism and strong legal pluralism. ${ }^{35}$ The concept of "weak legal pluralism" is also understood as state legal pluralism, which is another form of legal centralism that places state law in a superior position while other laws are in a hierarchy under state law. ${ }^{36}$ Meanwhile, the concept of "strong legal pluralism" gives place to all legal systems in the same position so that it creates interaction and there is no domination between one legal system and another. ${ }^{37}$ Within the framework of legal pluralism, it provides an understanding that state law recognizes legal pluralism. It can be understood that customary law is seen as an integral part of the state legal system. ${ }^{38}$ In line with Griffiths' idea, Werner Menski reiterates 3 (three) main elements in the concept of legal pluralism namely society, the state, and values and ethics that interact and influence each other. 39

By virtue of making a breakthrough in the legal framework of the balance between national and regional finances, the existence of customary villages may serve as an option for a solution. The customary villages, as implemented in Bali, may assist both national and regional governments to run the management in areas of natural resources. Therefore, customary village indirectly plays a role in achieving justice, equity, and harmony in the regions. Therefore, the synergy between the national government, regional governments, and customary villages, undoubtedly reflects legal pluralism.

\section{CONCLUSION}

Efforts to improve the relationship between the national and local governments in the context of the finance sector include the legal framework for the distribution of resources. The arrangement for the distribution of profit-sharing funds based on decentralization in Indonesia does not reflect the principle of proportionality. There remains an issue of injustice following the distribution scheme, e.g. oil and gas as well as tourism sectors, that give smaller portions of revenue to regions that having natural resources compare to what lies to the national government.

The existence of a customary community, customary law, and its traditional rights are guaranteed by the Indonesian Constitution. Bali may be used as an example of how customary villages may play a role to manage

35 von Benda-Beckmann, Franz. "Who's afraid of legal pluralism?." The Journal of Legal Pluralism and Unofficial Law 34, no. 47 (2002): 47.

36 Dewi, loc. cit.

37 Wahyu Nugroho. "Konsep Integrasi Kebijakan Pengelolaan Pertambangan Perspektif Pluralisme Hukum Di Indonesia.” Masalah-Masalah Hukum 48, no. 4 (2019): 405.

38 Anak Agung Istri Ari Atu Dewi, I Gede Pasek Pramana, and Putu Edgar Tanaya. "Hukum Adat Dan Hukum Nasional: Elaborasi Dalam Penyelenggaraan Pemerintah Daerah Mewujudkan Keseiahteraan Masvarakat." www.mpr.ao.id: 126.

39 I Putu Sastra Wibawa. "Perlindungan dan Pelestarian Bende ga Se bagai Organi sasi Tradisional Nelayan di Bali." Dharmasmrti: Jurnal Imu Agama dan Kebudayaan 20, no. 1 (2020): 73. 
the natural resources that parallel with the effort in achieving wealth in the region. Some regional regulations have strengthened the position of the customary village to maintain the sustainability of natural resources in Bali, which is known as wana kerthi (forestry) and segara kerthi (fisheries). The synergy between national and regional governments as well as customary village s indeed indicates implementation of the legal pluralism.

\section{BIBLIOGRAPHY}

\section{Book}

Ahmad, Ehtisham, and Ali Mansoor. "Indonesia: managing decentralization." In Managing Fiscal Decentralisation edited by Ethisham Ahmad and Vito Tanzi, 1-21, London and New York: Routledge, 2002.

Alisjahbana, Armida S. "7. Does Indonesia have the Balance Right in Natural Resource Revenue Sharing?." In The Politics And Economics Of Indonesia's Natural Resources, edited by Budy P. Resosudarmo, 109124. Singapore: ISEAS Publishing, 2005.

Bahl, Rov, and Bavar Tumennasan. "How Should Revenues From Natural Resources be Shared in Indonesia?." In Reforming Intergovernmental Fiscal Relations and the Rebuildina of Indonesia: The'Bia Bana'Proaram and its Economic Consequences, edited by edited by James Alm, Jorge Martinez-Vazquez, Sri Mulyani Indrawati, 199-233. United Kingdom: Edward Elgar, 2004.

Grafton, Quentin, et.al.. The economics of the environment and natural resources. New York: John Wiley \& Sons, 2008.

\section{Journal Article}

Atmadia, Anantatiwikrama Tungga, Nengah Bawa Atmadia, and Tuti Maryati. "Pecalang Segara: Satuan Tugas Keamanan Tradisional Penjaga Kelestarian Lingkungan Pantai dan Laut: Studi Kasus di Desa Pakraman Pemuteran, Grokgak, Buleleng, Bali." Jurnal Bumi Lestari 13, no. 1 (2013): 174-184.

Bakti, Baktu. "Pluralisme Hukum dalam Mekanisme Penyelesaian Sengketa Sumber Daya Alam di Aceh." Kanun Jurnal Ilmu Hukum 17, no. 1 (2015): 129-149.

Butt, Simon, and Fritz Edward Siregar. "State Control Over Natural Resources in Indonesia: Implications Of The Oil And Natural Gas Law Case of 2012." Journal of Energy \& Natural Resources Law 31, no. 2 (2013): 107-121. https://doi.org/10.1080/02646811.2013.11435324.

Dewi, Anak Agung Istri Ari Atu, "Eksistensi Otonomi Desa Pakraman dalam Perspektif Pluralisme Hukum." Jurnal Magister Hukum Udayana 3, no. 3 (2014).

515- 528 https://doi.org/10.24843/JMHU.2014.v03.i03.p13

Dewi, Anak Agung Istri Ari Atu, I. Gede Pasek Pramana, and Putu Edgar Tanaya. "Hukum Adat dan Hukum Nasional: Elaborasi Dalam Penyelenggaraan Pemerintah Daerah Mewujudkan Kesejahteraan Masyarakat." www. mpr. go. id: 115-150. 
Dwijayanthi, Putri Triari, Kali Jones, and N. G. A. D. Satyawati. "Indigenous People, Economic Development and Sustainable Tourism: A Comparative Analysis Between Bali, Indonesia and Australia." Udayana Journal of law and Culture 1, no. 1 (2017): 16-30. https://doi.org/10.24843/UJLC.2017.v01.i01.p02

Ferdiansyah, Irfan, Dwi Risma Deviyanti, and Salmah Pattisahusiwa. "Pengaruh Pendapatan Asli Daerah, Dana Alokasi Umum, Dana Alokasi Khusus, Dan Dana Perimbangan Terhadap Belanja Daerah." $\begin{array}{lllll}\text { INOVASI } & 14, & \text { no. } & 1 & \text { (2018): }\end{array}$ http://dx.doi.org/10.29264/jinv.v14i1.3546

Hamzah, Herdiansyah. "Legal Policy of Legislation in the Field of Natural Resources in Indonesia." Hasanuddin Law Review 1, no. 1 (2016): 108-121. http://dx.doi.org/10.20956/halrev.v1i1.218

Hidayat, Rachmat. "Political devolution: Lessons from a decentralized mode of government in Indonesia." SAGE open 7, no. 1 (2017): 1-11. https://doi.org/10.1177/2158244016686812

Isharyanto, Johan Erwin. "Pengelolaan Sumberdaya Perikanan Dalam Kerangka Undang-Undang Otonomi Daerah." Jurnal Ilmiah Hukum Dan Dinamika Masyarakat 15, no. 1 (2018): 34-44. http:/ / dx.doi.org/10.36356/hdm.v15i1.638

Ledyawati, "Kewenangan Pemerintah Daerah Dalam Pengelolaan Sumber Daya Alam Pertambangan Minerba di Era Otonomi Daerah." Jurnal Agregasi: Aksi Reformasi Government dalam Demokrasi 5, no. 1 (2017): 39-50.

Listijowati. "Tinjauan Yuridis Kedudukan Dan Hubungan Antara DPRD dan Pemerintah Daerah Menurut UU. 32 Tahun 2004 tentang Pemerintah Daerah.” Justice Pro: Jurnal Ilmu Hukum 2, no. 1 (2018): 53-69. https://doi.org/10.53027/jp.v2i1.230

Mbow, Cheikh, Mark Halle, Rabih El Fadel, and Ibrahim Thiaw. "Land resources opportunities for a growing prosperity in the Sahel." Current Opinion in Environmental Sustainability 48 (2021): 85-92. https://doi.org/10.1016/j.cosust.2020.11.005

Mudayen, Yohanes Maria Vianey and Herry Maridjo. "The Impacts of Fiscal Decentralization, Institutional Transformation, and Regional Revenue on Income Disparities between Provinces in Indonesia." Journal of Economics, Business, \& Accountancy Ventura 20, no. 3 (2018): 247259. http://dx.doi.org/10.14414/jebav.v20i2.878

Muin, Fatkhul. "Otonomi Daerah Dalam Perspektif Pembagian Urusan Pemerintah-Pemerintah Daerah dan Keuangan Daerah." Fiat Justisia 8, no. 1 (2014): 69-79. https://doi.org/10.25041/fiatjustisia.v8no1.288

Nugroho, Wahyu. "Konsep Integrasi Kebijakan Pengelolaan Pertambangan Perspektif Pluralisme Hukum di Indonesia" Masalah-Masalah Hukum 48, no. 4 (2019): 402-410. https: / / doi.org/ 10.14710/mmh.48.4.2019.402-410

Ribot, J. C., Agrawal, A., \& Larson, A. M. "Recentralizing While Decentralizing: How National Governments Reappropriate Forest Resources." World Development 34 no. 11 (2006): 1864-1886. DOI: https://doi.org/10.1016/j.worlddev.2005.11.020 
Rideng, I. W., Astara, I. W. W., \& Nahak, S. Model Pengelolaan Hutan Desa Berbasis Desa Adat di Desa Selat, Kabupaten Buleleng. Community Service Journal 1, no. 1 (2018). 8-14

Said, Abdul Rauf Alauddin. "Pembagian Kewenangan Pemerintah PusatPemerintah Daerah Dalam Otonomi Seluas-Luasnya Menurut UUD 1945." Fiat Justisia: Jurnal Ilmu Hukum 9, no. 4 (2015): 577-602. https://doi.org/10.25041/fiatjustisia.v9no4.613

Sulistiawan, Anggit, Budi Ispriyarso, and Aprista Ristyawati. "Bentuk dan Mekanisme Perencanaan Keuangan Daerah yang Partisipatif Guna Mewujudkan Akuntabilitas Publik." Jurnal Pembangunan Hukum Indonesia $1, \quad$ no. 2 (2019): 157. https://doi.org/10.14710/jphi.v1i2.146-157

von Benda-Beckmann, Franz. "Who's Afraid of Legal Pluralism?." The Journal of Legal Pluralism and Unofficial Law 34, no. 47 (2002): 37-82. https: / / doi.org/10.1080/07329113.2002.10756563

Wibawa, I. Putu Sastra. "Perlindungan dan Pelestarian Bendega sebagai Organisasi Tradisional Nelayan di Bali." Dharmasmrti: Jurnal Ilmu Agama dan Kebudayaan 20, no. 1 (2020): 6776. https://doi.org/10.32795/ds.v20i1.643

\section{Legal Documents}

Indonesia. The 1945 Constitution of the Republic of Indonesia. - The Decree of the People's Consultative Assembly No: I/MPR/2003 concerning the Review of the Material and Legal Status of the Decree of the People's Consultative Assembly of the Republic of Indonesia 1960 to 2002.

. The Decree of the People's Consultative Assembly of the Republic of Indonesia No. XV/MPR /1998 on the implementation of regional autonomy; Settings; division; and equitable utilization of national resources; and Central and regional financial balance in the framework of the Unitary State of the Republic of Indonesia.

. Law of the Republic of Indonesia No. 17 of 2003 on State Finances

. Law of the Republic of Indonesia No. 32 of 2004 concerning Regional

Government

. Law of the Republic of Indonesia No.33 of 2004 concerning the Financial Balance between the National Government and Regional Governments.

. Law of the Republic of Indonesia No. 28 of 2009 concerning Local Taxes and Changes.

. Law of the Republic of Indonesia No. 6 of 2014 concerning Customary Villages.

. Law of the Republic of Indonesia No. 23 of 2014 concerning Regional Government.

. Government Regulation No. 12 of 2019 concerning The Management of Regional Finance and Minister of Domestic Affairs Regulation No. 77 of 2020 concerning Technical Guidance on the Management of Regional Finance 
Bali Province. Bali Provincial Regulation No. 4 of 2019 concerning Customary Villages.

. Bali Governor Regulation No. 26 of 2020 concerning Integrated Environmental Security System Based on Customary Village.

\section{Other Documents}

Manley, David, Rani Febrianti and Hari Subhash, "Tangled Web: The Role of Oil, Gas and Mining in Funding Regional Government in Indonesia," Natural Resource Governance Institute, January 2020, https://resourcegovernance.org/sites/default/files/documents/tangl ed-web-the-role-of-oil-gas-and-mining-in-funding-regionalgovernments-in-indone sia.pdf

Strachan, Anna Louise. Oil and gas revenue sharing. Vol. 1123. GSDRC Helpdesk Research Report, 2014. http://www.gsdrc.org/docs/open/hdq1123.pdf

\section{Case Law}

Constitutional Court of Indonesia. Decision of the Constitutional Court of Indonesia No. 31/PUU-V/2007.

. Decision of the Constitutional Court of Indonesia No. 71/PUUIX/2011.

\section{Website Content}

Dinas Pemajuan Masyarakat Adat Pemerintah Bali. "Visi dan Misi." https://dpma.baliprov.go.id/visi-dan-misi/

Nurjaya, I Nyoman Nurjaya, "Perkembangan Pemikiran Konsep Pluralisme Hukum." Paper presented in Konferensi Internasional tentang Penguasaan Tanah dan Kekayaan Alam di Indonesia yang Sedang Berubah: "Mempertanyakan Kembali Berbagai , Jakarta (2004): 1-17. Available in https://docplayer.info/35514477-Perkembanganpemikiran-konsep-pluralisme-hukum-1.html 